\title{
Evaluating the effect of partial contributing storage on the storage-discharge function from recession analysis
}

\author{
X. Chen and D. Wang \\ Department of Civil, Environmental, and Construction Engineering, University of Central Florida, \\ 4000 Central Florida Blvd., Orlando, FL 32816, USA
}

Correspondence to: D. Wang (dingbao.wang@ucf.edu)

Received: 24 April 2013 - Published in Hydrol. Earth Syst. Sci. Discuss.: 7 May 2013

Revised: 17 September 2013 - Accepted: 26 September 2013 - Published: 31 October 2013

\begin{abstract}
Hydrograph recession during dry periods has been used to construct water storage-discharge relationships and to quantify storage dynamics and evaporation when streamflow data is available. However, variable hydrologic connectivity among hillslope-riparian-stream zones may affect the lumped storage-discharge relationship, and as a result, affect the estimation of evaporation and storage change. Given observations of rainfall and runoff, and remote-sensing-based observations of evaporation, the ratio $(\alpha)$ between estimated daily evaporation from recession analysis and observed evaporation, and the ratio $(\beta)$ between estimated contributing storage and total watershed storage are computed for 9 watersheds located in different climate regions. Both evaporation and storage change estimation from recession analysis are underestimated due to the effect of partial contributing storage, particularly when the discharge is low. It was found that the values of $\alpha$ decrease significantly during individual recession events, while the values of $\beta$ are relatively stable during a recession event. The values of $\beta$ are negatively correlated with the water table depth and vary significantly among recession events. The partial contributing storage effect is one possible cause for the multi-valued storage-discharge relationship.
\end{abstract}

\section{Introduction}

Partition, storage, and release are the three basic functions of a watershed (Wagener et al., 2007). Storages are the state variables characterizing the status of the hydrologic system. The terrestrial water storage anomalies, which are estimated using satellite data from the Gravity Recovery and Climate
Experiment (GRACE), are spatially averaged over regions that have areas of $1000000 \mathrm{~km}^{2}$ and greater (Swenson et al., 2006). However, the observation data on the watershed water storage or dynamic storage change are usually not available at the watershed scale. In some studies, storage changes are estimated from localized measurements of piezometer wells and soil moisture probes (Wang, 2012a), but the estimation is strongly dependent on spatial heterogeneity of subsurface properties (Kirchner, 2009). The dynamic storage change can also be estimated as the residual by water balance (Sayama et al., 2011); however, this method is constrained by data availability and the uncertainty with observations or estimations, especially evapotranspiration $(E)$. Therefore, it is a challenge to provide techniques and methods to quantify integrated storages at the watershed scale (Beven, 2006).

Given streamflow observations, watershed fluxes (precipitation or evapotranspiration) and water storages can be estimated by storage-discharge functions based on the streamflow recession analysis proposed by Brutsaert and Nieber (1977). Kirchner (2009) characterized a watershed water balance using a single nonlinear storage-discharge relationship derived from recession curves and demonstrated its utility for both hydrologic prediction and inversion (e.g., reconstructing precipitation and evaporation records from a streamflow hydrograph). Teuling et al. (2010) applied the simple dynamical systems approach to simulate streamflow dynamics for the Rietholzbach watershed in northeastern Switzerland. In both studies, the streamflow dynamics were modeled very well by constructing watershed storagedischarge functions based on high quality observation data. Using storage-discharge relationships derived from recession flow analysis, Ajami et al. (2011) quantified mountain 
block recharge by estimating changes in storage during wet periods. Krakauer and Temimi (2011) characterized the streamflow recession pattern in 61 relatively undisturbed small watersheds with hourly streamflow data and estimated the seasonal and interannual storage variations inferred from storage-discharge functions based on the recession curves. Applying a nonlinear storage-discharge function, Szilagyi et al. (2007) computed watershed-scale $E$ during flow recession periods with the help of a lumped version of the water balance equation for a watershed. Using a similar method, Palmroth et al. (2010) estimated long-term annual evapotranspiration at 11 watersheds in North Carolina and compared the estimated annual $E$ with that estimated using an eddy covariance method and a biochemical and ecophysiological model. Wang (2011) applied the recession analysis to estimate bedrock leakage and return flow from bedrock water storage.

The estimated evaporation and water storage dynamics from the lumped storage-discharge relationship are usually used to represent the entire watershed. The underlying assumption is that all of the subsurface storage in the watershed contributes to the streamflow observed at the outlet (Wang, 2012b). In these studies, a one-to-one relationship between storage and discharge was used and the estimated dynamic storage changes represent values at the watershed scale. However, in some watersheds, a storage-discharge function may only represent a partial storage of the watershed. Violating this assumption may affect the evaporation and storage change estimation significantly, especially in large watersheds with considerable spatial heterogeneity of soil water storage.

The connectivity of water storage contributing to streamflow varies spatially and temporally, especially during dry periods. During dry periods, not all of the landscape components (hillslope, riparian and stream zones) are hydrologically connected to the watershed outlet and further contribute to the observed base flow. In subsurface hydrology, spatial heterogeneity of hillslope-riparian-stream zones has been found to be an important factor in water table response to precipitation (Ewen and Birkinshaw, 2007; Vidon, 2012) and base flow recession behavior (Clark et al., 2009; Harman et al., 2009). Moreover, at the plot scale, water table dynamics can be independent of streamflow in hillslope and riparian zones (Seibert et al., 2003; Vidon and Hill, 2004; Rodhe and Seibert, 2011). Due to this spatial heterogeneity, the flowing stream network expands to respond to rainfall events and contracts during drought periods (Gregory, 1976; Day, 1978). Biswal and Marani (2010) demonstrated the linkage between base flow recession and the spatial organization of stream networks with a focus on the contraction of active stream networks. Even in an active stream network, the hydrologic connectivity of riparian and upland zones to a channel may decrease during dry periods (Ocampo et al., 2006; Molenat et al., 2008). Some river reaches may even become entirely detached from the riparian zone at very low flows due to obstruction of the channel by vegetation (Blyth and Rodda, 1973). Riparian zones are the interfaces between hillslopes and streams; water table fluctuations in riparian zones are usually not significant (Jencso et al., 2009). Even within hillslope or riparian zones, bedrock depressions can be disconnected during low flow periods (McDonnell et al., 1998; Buttle et al., 2004; Tromp-van Meerveld and McDonnell; 2006a, b).

Since the hydrologic connectivity between hillslope, riparian, and stream zones varies with time, the storagedischarge function may also vary when total watershed storage is used in the lumped discharge model. The variable characteristic of the storage-discharge function has been reported by several studies (e.g., Rupp et al., 2009). Using a linearized distributed model, Sloan (2000) found that total water storage and groundwater discharge is not a oneto-one relationship. A hysteresis-type relationship between storage and streamflow has been reported due to the variable hydrologic connectivity of water storage (Spence et al., 2010). Clark et al. (2011) demonstrated that a multi-valued storage-discharge relationship could be replicated by a simple lumped conceptual model with two parallel stores representing the saturated zone. Krakauer and Temimi (2011) reported that storage change estimated from base flow recession is underestimated compared with GRACE-based estimation.

Therefore, it is necessary to assess the potential impact of one-to-one storage-discharge relationships on evaporation and storage change estimations. The objective of this study is to evaluate the effect of partial contributing storage resulting from variable subsurface hydrologic connectivity on water storage-discharge relationships derived from recession analysis. Evaporation estimation based on remotely sensed data over large spatial scales and with high resolution is utilized for the assessment (Mu et al., 2007; Zhang et al., 2010). In this paper, the estimation of evaporation and storage change using storage-discharge functions will be evaluated based on observed rainfall, streamflow, and observed evaporation from remote sensing data for 9 watersheds located in different climate regions. The ratio between estimated daily evaporation from recession analysis and observed evaporation, and the ratio between estimated contributing storage and total watershed storage are computed for the 9 study watersheds. Their temporal variability is then discussed.

\section{Methodology}

\subsection{Recession analysis}

Hydrograph recession analysis is often utilized to derive water storage-discharge functions at the watershed scale. In the recession analysis method proposed by Brutsaert and Nieber (1977), recession slope $(-\mathrm{d} Q / \mathrm{d} t)$ is plotted as a function of discharge $(Q)$. This method facilitates the analysis on 


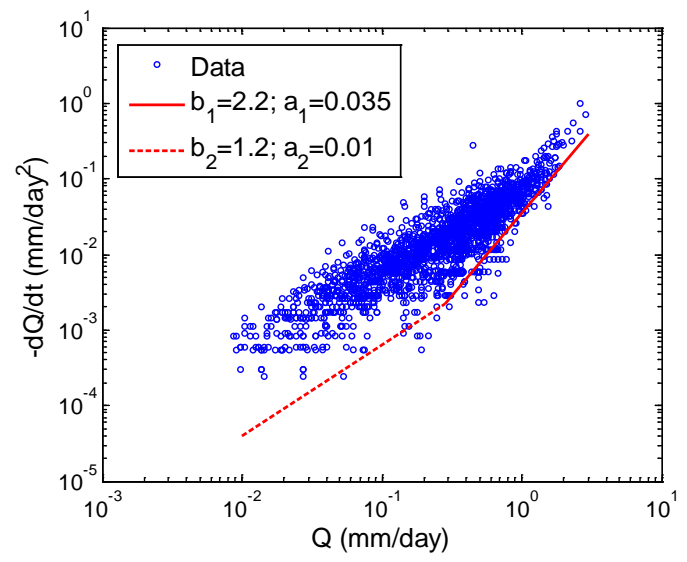

Fig. 1. $-\mathrm{d} Q / \mathrm{d} t$ versus $Q$ and the lower envelope for the Spoon River watershed based on daily streamflow data for the period of 1 January 1983-31 December 2003.

a collection of recession events and minimizes the impact of recession starting time on parameter estimation. As proposed by Brutsaert and Nieber (1977), the relationship between recession slope and discharge can be modeled as a power function:

$-\frac{\mathrm{d} Q}{\mathrm{~d} t}=a Q^{b}$

Exponent $b$ is dimensionless and the unit of $a$ depends on the value of $b . Q\left(\mathrm{~mm} \mathrm{day}^{-1}\right)$ is groundwater discharge per unit watershed area. The data pairs $\left(-\frac{\mathrm{d} Q}{\mathrm{~d} t}, Q\right)$ can be computed by the difference of discharges in consecutive days $\left(Q_{t}-Q_{t+1}\right)$ and the average discharge $\left(\left(Q_{t}-Q_{t+1}\right) / 2\right)$, respectively (Brutsaert and Nieber, 1977). Recession periods were selected when there was no rainfall. As an example, the data pairs $\left(-\frac{\mathrm{d} Q}{\mathrm{~d} t}, Q\right)$ for the Spoon River watershed are plotted in Fig. 1.

Based on the plot of $-\frac{\mathrm{d} Q}{\mathrm{~d} t}$ versus $Q$ on $\log -\log$ space, the function of $-\frac{\mathrm{d} Q}{\mathrm{~d} t}=f(Q)$ and, further, the storage-discharge function can be constructed. Several methods have been used to estimate the parameters in the literature (Ding, 1966, 2012; Stoelzle et al., 2013). Vogel and Kroll (1992) estimated the parameter values in Eq. (1) by linear regression. Kirchner (2009) proposed the use of polynomial functions to fit the binned data points from the recession analysis. Therefore, the power function in Eq. (1) was not assumed a priori. Since the recession rate of groundwater discharge is smaller than other storage components, Brutsaert and Nieber (1977) proposed placing a fitted line at the lower envelope of the data points. The effect of evaporation on recession parameter estimation is minimal at the lower envelope. In this study, the lower envelope method is used for estimating the recession parameters $a$ and $b$. Furthermore, the recession period is separated into early recession and late recession with two pairs of parameters, $\left(a_{1}, b_{1}\right)$ and $\left(a_{2}, b_{2}\right)$, respectively.
When there is no rainfall and the net groundwater flux from outside the watershed is negligible, the water balance equation during recession events can be written as

$\frac{\mathrm{d} S}{\mathrm{~d} t}=-Q-E$,

where $S(\mathrm{~mm})$ is the depth of water storage contributing to observed base flow at the outlet, normalized over the entire watershed area. Similarly, $E(\mathrm{~mm})$ is the depth of evaporation from the contributing storage, normalized by the watershed area. Both $S$ and $E$ are not the corresponding total values for the entire watershed. The storage-discharge function derived from hydrograph recession is a conceptual lumped model. The unsaturated and saturated zones are modeled by one storage term. Therefore, evaporation in Eq. (2) is assumed to represent the total evaporation from both unsaturated and saturated zones (Szilagyi et al., 2007; Kirchner, 2009; Palmroth et al., 2010).

The recession parameters can be estimated at the lower envelope where the impact of evaporation is minimal (Fig. 1). Combining Eq. (2) when the evaporation impact is minimal with Eq. (1), the storage-discharge relationship is obtained:

$\mathrm{d} S=\frac{1}{a} Q^{1-b} \mathrm{~d} Q$

Substituting $\mathrm{d} S$ into Eq. (2), evaporation can be estimated based on the observed recession slope and discharge (Palmroth et al., 2010):

$E=\frac{-\mathrm{d} Q / \mathrm{d} t}{a} Q^{1-b}-Q$.

The effect of evaporation on hydrograph recession has been reported in many watersheds (Federer, 1973; Daniel, 1976). The seasonal variability of recession rate is caused by seasonal patterns of evaporation (Wittenberg and Sivapalan, 1999).

During the late recession, the exponent, which is represented by $b_{2}$, is usually less than 2 . The contributing storage is obtained by integrating Eq. (3):

$S=S_{\mathrm{m}}+\frac{Q^{2-b_{2}}}{a_{2}\left(2-b_{2}\right)}$,

$S_{\mathrm{m}}$ is interpreted as the minimum storage for generating base flow, which is set to 0 in this study.

During the early recession, the exponent, which is represented by $b_{1}$, is usually larger than 2 . The contributing storage is computed as

$S=S_{\mathrm{c}}+\frac{Q^{2-b_{1}}}{a_{1}\left(2-b_{1}\right)}$,

$S_{\mathrm{c}}$ is interpreted as the storage capacity (Kirchner, 2009). Storage and discharge functions based on Eq. (5), which are estimated from recession analysis as shown in Fig. 1, are usually assumed to be one-to-one relationships. 
Discharge at the transition point from early to late recessions is a function of four recession parameters:

$Q_{0}^{*}=\left(\frac{a_{2}}{a_{1}}\right)^{\frac{1}{b_{1}-b_{2}}}$.

For the parameters in Fig. $1, Q_{0}^{*}$ is $0.29 \mathrm{~mm} \mathrm{day}^{-1}$ for the Spoon River watershed. If $Q>Q_{0}^{*}$, the recession is at the early stage. Otherwise, it is at the late stage. According to Eq. (5), the storage capacity can be computed given $S_{\mathrm{m}}$ and $Q_{0}^{*}$ :

$S_{\mathrm{c}}=S_{\mathrm{m}}+\frac{Q_{0}^{*^{2-b_{2}}}}{a_{2}\left(2-b_{2}\right)}-\frac{Q_{0}^{*^{2-b_{1}}}}{a_{1}\left(2-b_{1}\right)}$.

Storages for the late and early recessions are computed by Eqs. (5) and (6), respectively.

As discussed earlier, due to the effect of partial contributing storage, $S$ in these equations is the contributing storage normalized by the watershed area. The ratio of contributing storage to total storage is represented by $\beta$ :

$\beta=\frac{S}{\mathrm{TS}}$

where TS ( $\mathrm{mm})$ is the total depth of water storage per unit watershed area. Similarly, the ratio of evaporation estimated by Eq. (4) to total evaporation is represented by

$\alpha=\frac{E}{\mathrm{TE}}$

where TE $(\mathrm{mm})$ is the total evaporation per unit watershed area. The variables $\alpha$ and $\beta$ can be interpreted as the fraction of the watershed underlain by aquifers that contributes to streamflow. The values of $\alpha$ and $\beta$ are indicators of hydrologic connectivity among hillslope-riparian-stream zones. The variability of $\beta$, such as seasonal variation, is one potential factor for variable storage-discharge functions, at the watershed scale.

\subsection{Estimation of $\alpha$ and $\beta$}

In order to explore the impact of the variable contributing storage on the storage-discharge relationship, the values of $\alpha$ and $\beta$ are estimated in the study watersheds. At each individual recession event, $\alpha$ is estimated as the ratio between estimated daily $E$ from Eq. (4) and observed daily evaporation $\left(E^{\mathrm{obs}}\right)$ based on remote sensing data at the watershed scale.

$\beta$, however, is estimated as the ratio between estimated storage and total storage. For a recession segment, the value of $\beta$ is estimated by the water balance described as follows. Storages at two consecutive days, $S\left(t_{1}\right)$ and $S\left(t_{2}\right)$, are computed by Eq. (5). The total watershed storage change is equal to the sum of discharge and total evaporation:

$\mathrm{TS}\left(t_{1}\right)-\mathrm{TS}\left(t_{2}\right)=Q\left(t_{2}\right)+\mathrm{TE}\left(t_{2}\right)$.
Combining equations (9) and (11), the contributing storage parameter at $t_{2}$ is computed by

$\beta\left(t_{2}\right)=\frac{S\left(t_{2}\right)}{\left[S\left(t_{1}\right) / \beta\left(t_{1}\right)-Q\left(t_{2}\right)-\mathrm{TE}\left(t_{2}\right)\right]}$.

At the onset of the recession event $\left(t_{1}\right)$, the value of $\beta$ is assumed to be equal to the average of $\alpha$ during the recession event, since $\alpha$ and $\beta$ are both primarily controlled by the variation of contributing storage in the watershed. This assumption is used for determining the initial value of $\beta$ in a recession event. The uncertainty of the initial value of $\beta$ does not affect the generalization of the findings.

The assumptions in this study are summarized as follows: (1) the storage in unsaturated and saturated zones is treated as one storage component; (2) the recession event includes early recession and late recession, which can be represented by two power relationships; (3) the contributing storage-discharge function is fixed and can be estimated by the lower envelope of the plot of $-\mathrm{d} Q / \mathrm{d} t \sim Q ;$ (4) the water balance during recessions can be described by Eq. (2); (5) for individual recession events, the initial value of $\beta$ is assumed to be equal to the average value of $\alpha$ during the event.

\subsection{Data selection and $S_{\mathrm{m}}$}

The analysis in this paper is based on recessions during the period of April-October in order to focus on the rainfall events. The following criteria are used to filter recession segments: (1) declining streamflow; (2) no rainfall during a recession event; (3) a recession event is longer than 4 days. The recession rate computed by $\frac{Q(t)-Q(t+2)}{2}$ is used to compute $S(t+1)$ associated with discharge $Q(t+1)$. The estimated storage in Eq. (5) is affected by the minimal storage $S_{\mathrm{m}}$, which is set to 0 . However, the estimation of evaporation in Eq. (4) is unaffected by $S_{\mathrm{m}}$.

\section{Study watersheds and data}

Table 1 shows the background information of 9 selected watersheds, including watershed name, USGS gage station identification number, drainage area, and climate aridity index. The values of climate aridity index for the watersheds range from 0.38 to 1.34 . Rainfall and runoff data during the period of 1948-2003 were obtained from the Model Parameter Estimation Experiment (MOPEX) data set (Duan et al., 2006). Daily actual evaporation during the period of 19832006 was obtained from the data set developed by Zhang et al. (2010). Weather-station-based observations and normalized difference vegetation index (NDVI) from remote sensing data are utilized for evaporation estimation at each pixel with a spatial resolution of about $8 \mathrm{~km}$. The grid-based values of daily evaporation are aggregated to the watershed level. The evaporation algorithm accuracy was evaluated by comparing the estimated evaporation with tower-measured meteorology results from the FLUXNET data archive, which 
Table 1. Watershed name, USGS gage number, drainage area, climate aridity index $\left(E_{p} / P\right)$, and estimated recession parameters for the 9 case study watersheds.

\begin{tabular}{llrrrrrr}
\hline \multirow{2}{*}{ Watershed } & \multicolumn{1}{l}{$\begin{array}{l}\text { USGS } \\
\text { gage }\end{array}$} & $\begin{array}{r}\text { Drainage } \begin{array}{r}\text { area } \\
\left(\mathrm{km}^{2}\right)\end{array} \\
\end{array}$ & & & \multicolumn{4}{c}{$\begin{array}{c}\text { Recession } \\
\text { parameter }\end{array}$} \\
\cline { 5 - 9 } & & & & $a_{1}$ & $b_{1}$ & $a_{2}$ & $b_{2}$ \\
\hline Spoon River, IL & 05570000 & 4237 & 1.09 & 0.035 & 2.2 & 0.01 & 1.2 \\
Holston River, VA & 03473000 & 785 & 0.61 & 0.02 & 2.3 & 0.03 & 1.4 \\
Nantahala River, NC & 03504000 & 134 & 0.39 & 0.0015 & 2.9 & 0.01 & 1.5 \\
Little Sioux River, IA & 06606600 & 6475 & 1.34 & 0.022 & 2.5 & 0.02 & 1.5 \\
Valley River, NC & 03550000 & 265 & 0.38 & 0.004 & 3 & 0.017 & 1.5 \\
Clinch River, VA & 03524000 & 1380 & 0.68 & 0.025 & 2.9 & 0.035 & 1.5 \\
Powell River, VA & 03531500 & 827 & 0.60 & 0.025 & 2.9 & 0.035 & 1.5 \\
Nodaway River, IA & 06817000 & 1972 & 1.17 & 0.05 & 2.8 & 0.025 & 1.5 \\
Big Nemaha River, NE & 06815000 & 3468 & 1.34 & 0.15 & 3 & 0.025 & 1.3 \\
\hline
\end{tabular}

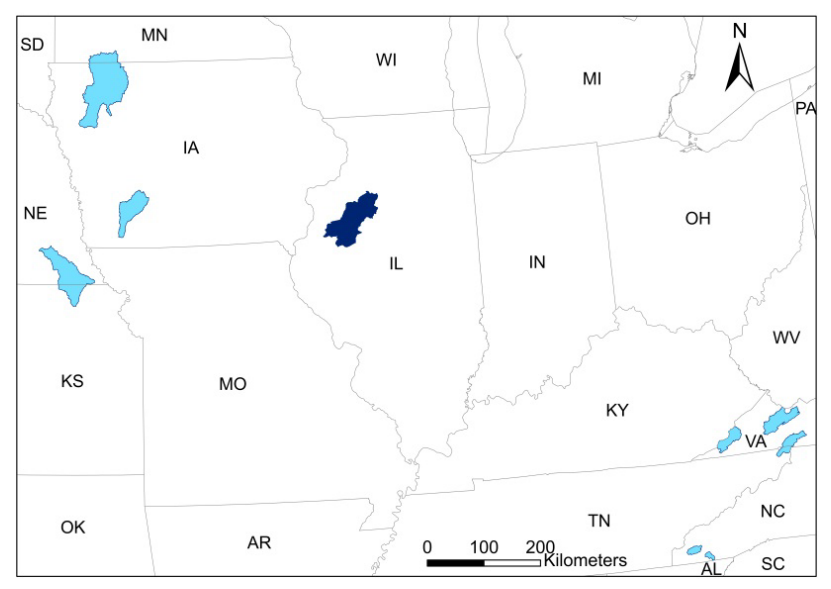

Fig. 2. Locations of the 9 study watersheds with Spoon River watershed located in Illinois and highlighted in dark blue.

are based on measurements from 82 tower sites (Zhang et al., 2010). Based on their results, the root mean square error (RMSE) of the estimated evaporation for sites in the United States is $32 \mathrm{~W} \mathrm{~m}^{-2}$, which is around $1.20 \mathrm{~mm} \mathrm{day}^{-1}$. Considering the availability of rainfall, runoff, and evaporation data, this study is focused on the period of 1983-2003.

Among the 9 study watersheds, Spoon River watershed located in Illinois will be discussed with more emphasis (Fig. 2) because of the rich data availability. Soil moisture observations during 1981-2004 and groundwater level observations since the 1960s are available (Changnon et al., 1988; Hollinger and Isard, 1994; Scott et al., 2010). These data sets can be used to explore the seasonal water storage changes directly (Wang, 2012a). The land cover in this watershed is primarily agricultural $(85 \%)$ and includes corn and soybean crops; the remaining land cover includes forest, barren, and urban lands (Demissie et al., 2007). The soil thickness of river riparian zones varies from 5 to $15 \mathrm{ft}$. (IDNR, 1998).

\section{Results and discussion}

The values of $\alpha$ and $\beta$ in the 9 case study watersheds shown in Table 1 are calculated using the method discussed above. The Spoon River watershed will be discussed in more details as mentioned previously. As shown in Fig. 1, the recession parameters for the Spoon River watershed are $b_{1}=2.2$ and $a_{1}=0.035$ for the early recession and $b_{2}=1.2$ and $a_{2}=0.01$ for the late recession. The values of the recession parameters for the other 8 watersheds are shown in Table 1 and the corresponding plots of $-\mathrm{d} Q / \mathrm{d} t \sim Q$ can be found in the Supplement.

\subsection{Underestimation of evaporation from base flow recession analysis}

Estimated daily evaporation from the lumped storagedischarge relationship is compared with evaporation estimated from remote-sensing- and weather-station-based data. For demonstration purposes, Table 2 shows two recession events: (1) the Spoon River watershed during May 1994 in Table 2a, and (2) the Nodaway River watershed during June 1995 in Table 2b. The estimated $E$ by Eq. (4) and $E^{\text {obs }}$ from remote sensing data are shown in columns 6 and 7, respectively. As can be seen in Table 2, the estimated evaporation from recession analysis is much smaller than $E^{\text {obs }}$. Figure 3 plots estimated $E$ versus $E^{\text {obs }}$ from all 9 watersheds. Most of the estimated values of evaporation are smaller than the remotely sensed values and $93 \%$ of data points are below the $1: 1$ line in Fig. 3.

There are two potential reasons that a mismatch between estimated $E$ versus $E^{\text {obs }}$ can be induced: either the values of $E$ are underestimated, or the values of $E^{\text {obs }}$ are overestimated. However, $E^{\text {obs }}$ is not biased toward overestimating evaporation as discussed earlier and the average RMSE of $E^{\text {obs }}$ is $1.2 \mathrm{~mm} \mathrm{day}^{-1}$. The detailed uncertainty assessment of $E^{\mathrm{obs}}$ is discussed in the next section. Even if $1.2 \mathrm{~mm}^{\mathrm{day}}{ }^{-1}$ of overestimation in $E^{\mathrm{obs}}$ is assumed, the estimated $E$ is still 
Table 2a. One recession event from the Spoon River watershed in Illinois in May 1994.

\begin{tabular}{|c|c|c|c|c|c|c|c|c|}
\hline Date & $\begin{array}{r}P \\
\left(\mathrm{~mm} \mathrm{day}^{-1}\right)\end{array}$ & $\begin{array}{r}Q \\
\left(\mathrm{~mm} \mathrm{day}^{-1}\right)\end{array}$ & $\begin{array}{r}-\mathrm{d} Q / \mathrm{d} t \\
\left(\mathrm{~mm} \mathrm{day}^{-12}\right)\end{array}$ & $\begin{array}{r}S \\
(\mathrm{~mm})\end{array}$ & $\begin{array}{l}\text { Estimated } E \\
\left(\mathrm{~mm} \mathrm{day}^{-1}\right)\end{array}$ & $\begin{array}{r}E^{\mathrm{obs}} \\
\left(\mathrm{mm} \mathrm{day}^{-1}\right)\end{array}$ & $\alpha$ & $\beta$ \\
\hline 05/15/1994 & 0.40 & 0.84 & & & & & & \\
\hline 05/16/1994 & 0.00 & 0.78 & & & & & & \\
\hline 05/17/1994 & 0.00 & 0.71 & 0.0665 & 76.22 & 2.18 & 3.33 & 0.656 & 0.437 \\
\hline 05/18/1994 & 0.00 & 0.65 & 0.0491 & 73.57 & 1.72 & 3.16 & 0.543 & 0.431 \\
\hline 05/19/1994 & 0.00 & 0.61 & 0.0373 & 71.55 & 1.33 & 3.08 & 0.432 & 0.429 \\
\hline $05 / 20 / 1994$ & 0.00 & 0.57 & 0.0258 & 69.71 & 0.86 & 3.10 & 0.278 & 0.427 \\
\hline 05/21/1994 & 0.00 & 0.56 & 0.0255 & 68.72 & 0.92 & 3.35 & 0.274 & 0.431 \\
\hline $05 / 22 / 1994$ & 0.00 & 0.52 & & & & & & \\
\hline $05 / 23 / 1994$ & 0.81 & 0.50 & & & & & & \\
\hline
\end{tabular}

Table 2b. One recession event from the Nodaway River watershed in Iowa in June 1995.

\begin{tabular}{|c|c|c|c|c|c|c|c|c|}
\hline Date & $\begin{array}{r}P \\
\left(\mathrm{~mm} \mathrm{day}^{-1}\right)\end{array}$ & $\begin{array}{r}Q \\
\left(\mathrm{~mm} \text { day }^{-1}\right)\end{array}$ & $\begin{array}{r}-\mathrm{d} Q / \mathrm{d} t \\
\left(\mathrm{~mm} \mathrm{day}^{-12}\right)\end{array}$ & $\begin{array}{r}S \\
(\mathrm{~mm})\end{array}$ & $\begin{array}{l}\text { Estimated } E \\
\left(\mathrm{~mm} \mathrm{day}^{-1}\right)\end{array}$ & $\begin{array}{r}E^{\mathrm{obs}} \\
\left(\mathrm{mm} \mathrm{day}^{-1}\right)\end{array}$ & $\alpha$ & $\beta$ \\
\hline 06/14/1995 & 0.51 & 0.70 & & & & & & \\
\hline 06/15/1995 & 0.00 & 0.65 & & & & & & \\
\hline 06/16/1995 & 0.00 & 0.60 & 0.0497 & 61.87 & 1.90 & 4.37 & 0.436 & 0.384 \\
\hline 06/17/1995 & 0.00 & 0.55 & 0.0428 & 59.46 & 1.75 & 4.02 & 0.435 & 0.357 \\
\hline 06/18/1995 & 0.00 & 0.51 & 0.0329 & 57.28 & 1.33 & 3.75 & 0.353 & 0.330 \\
\hline 06/19/1995 & 0.00 & 0.49 & 0.0298 & 55.81 & 1.22 & 3.91 & 0.313 & 0.319 \\
\hline 06/20/1995 & 0.04 & 0.45 & & & & & & \\
\hline
\end{tabular}

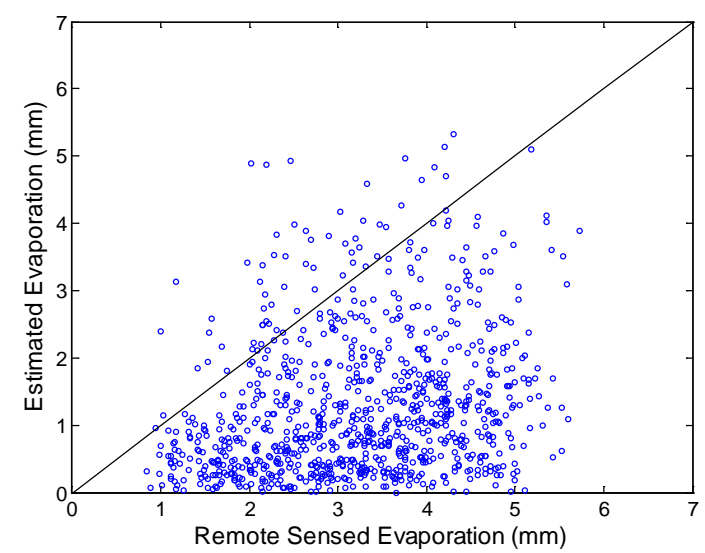

Fig. 3. Comparison between estimated evaporation from recession analysis and evaporation from remotely sensed data.

underestimated in most recession events. As shown in Table 2, the estimated $E$ decreased from 1.72 to $0.92 \mathrm{~mm} \mathrm{day}^{-1}$ during a recession event in May in the Spoon River watershed while $E^{\text {obs }}$ remained between the levels of 3.08 and $3.35 \mathrm{~mm} \mathrm{day}^{-1}$. The underestimation of $E$ is also supported by the fact that potential evaporation of the Spoon River watershed is $6.20 \mathrm{~mm} \mathrm{day}^{-1}$ and the land use is dominated by agricultural lands, which include corn and soybean crops (ISWS, 2010). It should be noted that the placement of the lower envelope in Fig. 1 also affects the estimation of $E$. If the lower envelope in Fig. 1 was moved upward, the estimated evaporation would be even lower.

The underestimation of evaporation from hydrograph recession analysis can be explained by two major reasons: (1) the storage contributing to the observed base flow in the outlet mainly comes from riparian groundwater during dry periods and, therefore, the estimated evaporation by Eq. (4) only accounts for evaporation from the riparian zone; (2) the linkage between water storage in the unsaturated zone and base flow becomes weak as the groundwater table declines. As a result, evaporation from the unsaturated zone is not included in the estimated $E$ from recession analysis. Because of these two reasons, the value of estimated $E$ from Eq. (4) will be underestimated, since the estimated $E$ from the riparian zone or the contributing storage to the base flow is normalized by the entire watershed area.

\subsection{Uncertainty of remote sensing-based evaporation data}

The detailed uncertainty assessment is provided in Zhang et al. (2010). As discussed in Sect. 4.1, even if the RMSE of $1.2 \mathrm{~mm} \mathrm{~d}^{-1}$ of the remotely sensed evaporation from Zhang et al. (2010) is considered an overestimation, the underestimation of evaporation from recession analysis is still significant. Furthermore, Zhang et al. (2010) compared the 


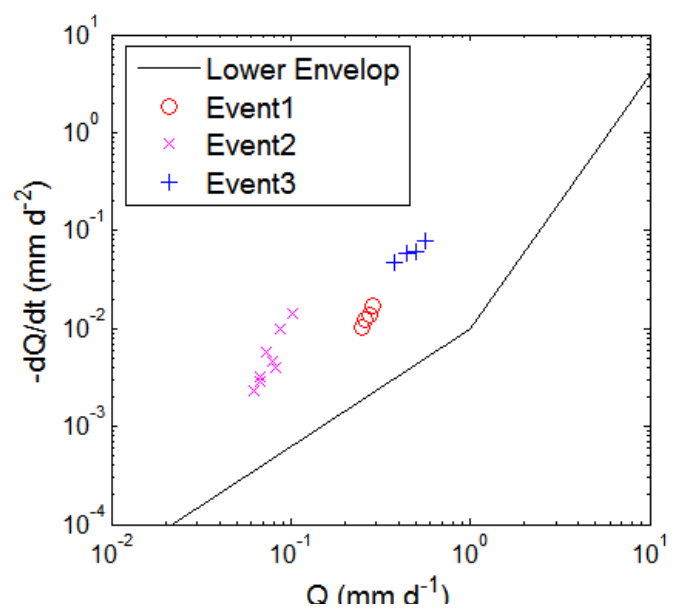

Fig. 4. The slopes of three individual recession events in the Spoon River watershed.

estimated multi-year mean annual $E$ based on remote sensing data (denoted as $E_{\mathrm{RS}}$,) with $E$ estimated from water balance (denoted as $E_{\text {Inferred }}$ ). Please see Fig. 8 of Zhang et al. (2010) for the illustration of this comparison. The percent difference between $E_{\mathrm{RS}}$ and $E_{\text {Inferred }}$ is within $\pm 10 \%$.

On the other hand, Zhang et al. (2010) also compared estimated daily latent heat based on remote sensing data with observed tower fluxes, and the correlation coefficient between them is around 0.85 (USBO1 station, which is located in Illinois, shown in Fig. 3 of Zhang et al., 2010). Two other performance indicators (MR and RMSE) are also shown in Fig. 5 of Zhang et al. (2010). The accuracy of $E_{\mathrm{RS}}$ is well-quantified as discussed in their study. As mentioned previously, the remotely sensed evaporation $E_{\mathrm{RS}}$ is represented by $E^{\mathrm{obs}}$ in this study.

The validation of $E^{\text {obs }}$ is provided in this study by comparing remote-sensing-based mean annual $E$ values for the Spoon River watershed with soil water balance. The multiyear (1983-2003) averaged $E$ estimated from remote sensing data is $642 \mathrm{~mm}$ for the Spoon River watershed. Based on soil water balance, Yeh et al. (1998) estimated the average annual $E$ for the state of Illinois to be $659 \mathrm{~mm}$. Based on the MOPEX data set, the mean annual rainfall is $922 \mathrm{~mm}$ and the mean annual runoff is $272 \mathrm{~mm}$; the mean annual evaporation is computed to be $650 \mathrm{~mm}$ by assuming negligible storage change. Therefore, the estimated evaporation $E^{\mathrm{obs}}$ is reasonable in the study watershed.

\subsection{Temporal variability of $\alpha$}

The ratio between estimated $E$ and $E^{\text {obs }}$, which is represented by $\alpha$, reflects the significance of bias in the estimated evaporation. As shown in Table $2 \mathrm{a}$, the value of $\alpha$ decreases by $58 \%$ from 0.656 to 0.274 during the recession event, while the value of $\alpha$ decreases by $28 \%$ from 0.436 to 0.313 during the event in Table $2 \mathrm{~b}$. In general, a decreasing

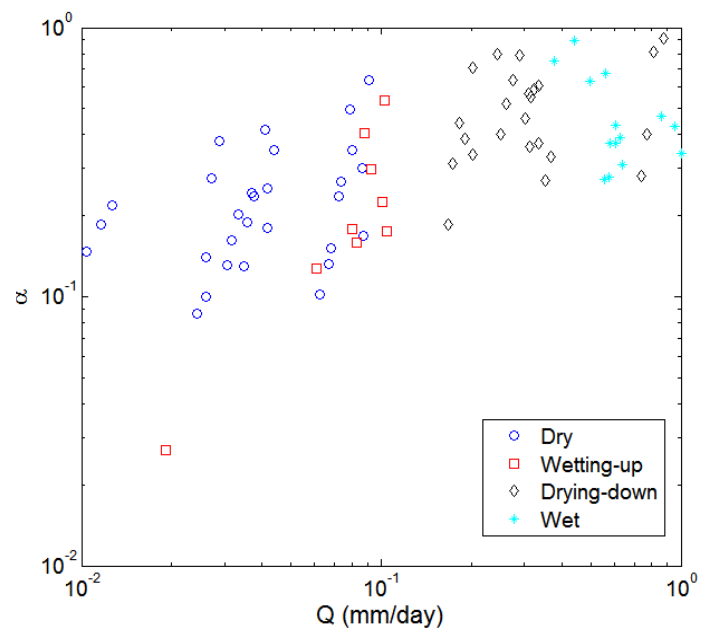

Fig. 5. Estimated $\alpha$ versus discharge $(Q)$ for the Spoon River watershed in 4 storage stages.

trend in values of $\alpha$ is observed in the majority of the recession events in all of the study watersheds. The decreasing trend can be interpreted as a decrease of contributing storage. On the other hand, the decrease of $\alpha$ can be interpreted as a decrease of vertical distance between the data point and the lower envelope, given that the $E^{\text {obs }}$ is relatively constant and the lower envelop is fixed (Table 2a). In other words, the slope of a single recession event is not the same as the slope of the lower envelope. Figure 4 and Table 3 show three recession events in the Spoon River watershed. As the data shows, when the slope of an individual event is larger than the slope of the lower envelope (slope $=1.20$ ) as shown in Event 1 (slope $=3.33$ ) and Event 2 (slope $=3.54)$, which is the most common case, the value of $\alpha$ will decrease during the recession. When the slope of the individual events is equal to or smaller than the lower envelope, as shown in Event 3 (slope $=1.13$ ), the value of $\alpha$ will stay relatively constant or even increase slightly due to the uncertainty of the evaporation data. However, for all three events, $\alpha$ is smaller than 1. The underestimation of evaporation is observed in most of the recession events, while the changing trend of $\alpha$ may be variable.

The value of $\alpha$ also varies with events and is dependent on the initial soil moisture and the groundwater table. For example, the water table rises after a heavy rainfall and, consequently, more groundwater area contributes to the base flow, which corresponds with a higher value of $\alpha$. At the same time, higher discharge corresponds with a higher water table. Figure 5 plots the relationship between estimated $\alpha$ and observed discharge for the Spoon River watershed. As the figure shows, larger values of $\alpha$ correspond with higher discharges. The $\alpha-Q$ relationship under 4 storage stages (dry, wetting-up, drying-down, and wet) will be presented in Sect. 4.5. 
Table 3. Three individual recession events in the Spoon River watershed.

\begin{tabular}{lrrrrrr}
\hline & $\begin{array}{r}\text { Date } \\
\left(\mathrm{mm} \mathrm{day}^{-1}\right)\end{array}$ & $\begin{array}{r}Q \\
\left(\mathrm{~mm} \mathrm{day}^{-12}\right)\end{array}$ & $\begin{array}{r}-\mathrm{d} Q / \mathrm{d} t \\
\left(\mathrm{~mm} \mathrm{day}^{-1}\right)\end{array}$ & $\begin{array}{r}E_{\text {obs }} \\
\left(\mathrm{mm} \mathrm{day}^{-1}\right)\end{array}$ & $E_{\text {est }}$ & $\alpha$ \\
\hline Event 1 & $5 / 3 / 1988$ & 0.2889 & 0.0171 & 2.39 & 1.90 & 0.793 \\
& $5 / 4 / 1988$ & 0.2745 & 0.0136 & 2.31 & 1.48 & 0.641 \\
& $5 / 5 / 1988$ & 0.2618 & 0.0122 & 2.54 & 1.33 & 0.523 \\
& $5 / 6 / 1988$ & 0.2502 & 0.0104 & 2.79 & 1.12 & 0.402 \\
\hline Event 2 & $6 / 13 / 1988$ & 0.1023 & 0.0142 & 3.97 & 2.14 & 0.539 \\
& $6 / 14 / 1988$ & 0.0878 & 0.0099 & 3.74 & 1.51 & 0.405 \\
& $6 / 15 / 1988$ & 0.0826 & 0.0041 & 3.69 & 0.58 & 0.158 \\
& $6 / 16 / 1988$ & 0.0797 & 0.0046 & 3.83 & 0.68 & 0.178 \\
& $6 / 17 / 1988$ & 0.0734 & 0.0058 & 3.33 & 0.90 & 0.269 \\
& $6 / 18 / 1988$ & 0.0682 & 0.0032 & 3.17 & 0.48 & 0.151 \\
& $6 / 19 / 1988$ & 0.0670 & 0.0029 & 3.27 & 0.43 & 0.132 \\
& $6 / 20 / 1988$ & 0.0624 & 0.0023 & 3.33 & 0.34 & 0.102 \\
\hline \multirow{2}{*}{ Event 3 } & $7 / 19 / 1986$ & 0.5623 & 0.0780 & 5.73 & 3.88 & 0.678 \\
& $7 / 20 / 1986$ & 0.4970 & 0.0607 & 5.54 & 3.52 & 0.635 \\
& $7 / 21 / 1986$ & 0.4409 & 0.0596 & 4.58 & 4.10 & 0.897 \\
& $7 / 22 / 1986$ & 0.3779 & 0.0480 & 5.36 & 4.03 & 0.751 \\
\hline
\end{tabular}

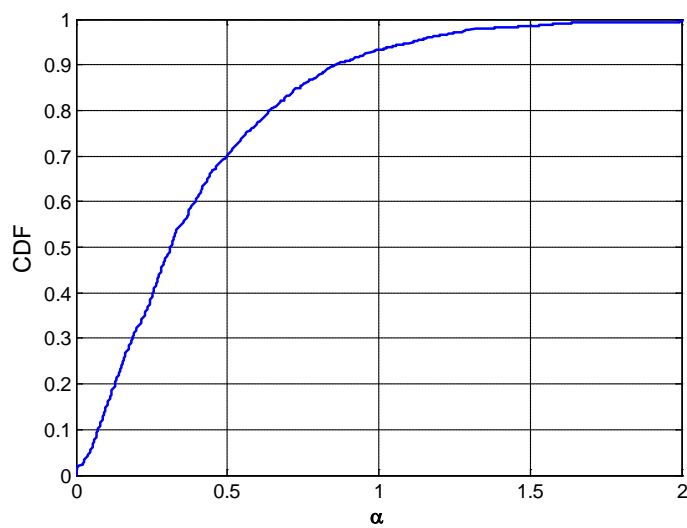

Fig. 6. Cumulative distribution function of $\alpha$ for all of the study watersheds.

As a statistical summary on the underestimation of $E$, Fig. 6 shows the cumulative distribution function (CDF) curve of $\alpha$, in which $93.3 \%$ of the $\alpha$ values in the 9 study watersheds are smaller than 1 and over $70.2 \%$ of the $\alpha$ values are smaller than 0.5 . This result indicates a significant underestimation of evaporation based on recession analysis.

\subsection{Temporal variability of $\beta$}

The underestimation of storage by the storage-discharge relationship is reflected in the values of $\beta$ (the ratio of estimated storage to total storage). Figure 7 plots the CDF curve of $\beta$ values in the 9 study watersheds. The values of $\beta$ are less than 1.0 for $94.5 \%$ of the data points, and are less than 0.5 for $72.7 \%$ of the data points. Focusing on small watersheds

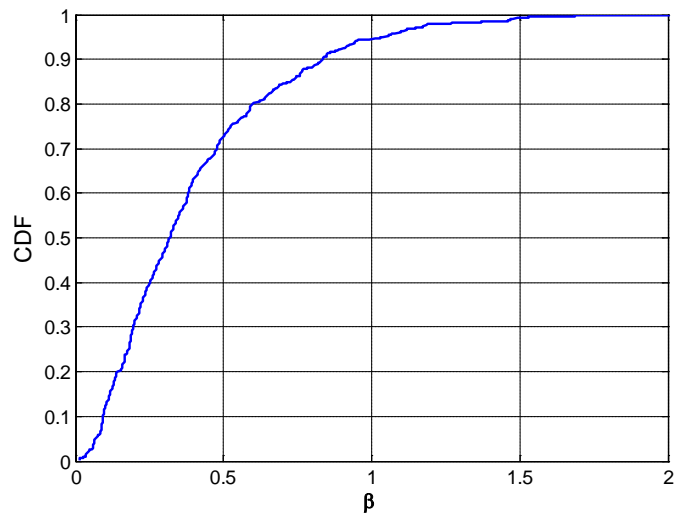

Fig. 7. Cumulative distribution function of $\beta$ for all of the study watersheds.

with a drainage area smaller than $100 \mathrm{~km}^{2}$, Krakauer and Temimi (2011) compared the storage inferred from the recession curve and the storage measured by GRACE and found that the variability of storage by the storage-discharge functions derived from the recession curves is typically smaller by a factor of 10 . The effect of partial contributing storage contributes to the discrepancy that was also observed in their study.

The underestimations of both evaporation and storage change based on recession analysis are due to the effect of partial contributing storage on base flow. Furthermore, the storage changes between two consecutive days $(\Delta S$ and $\Delta \mathrm{TS})$ are computed, and the ratios between them, $\Delta S / \Delta \mathrm{TS}$, are obtained. Figure 8 plots $\Delta S / \Delta$ TS versus $\alpha$ (i.e., $E / E^{\text {obs }}$ ) for the Spoon River watershed. The correlation coefficient 


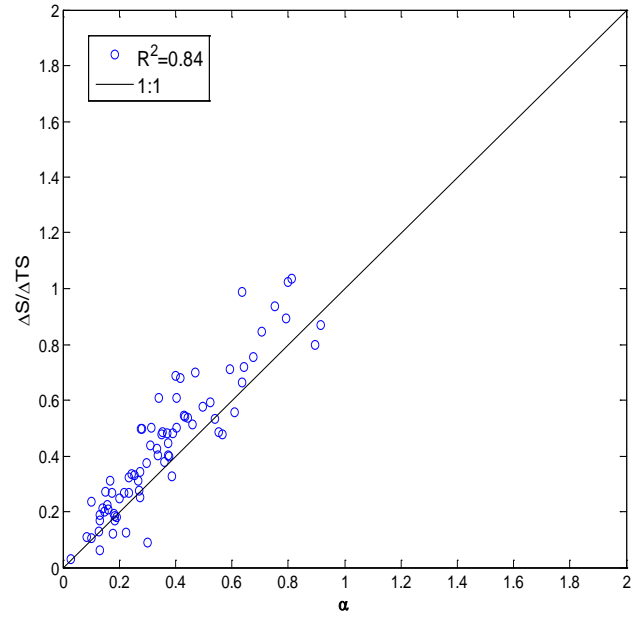

Fig. 8. Correlation between $\Delta S / \Delta \mathrm{TS}$ and $\alpha$ in the Spoon River watershed.

between $\Delta S / \Delta \mathrm{TS}$ and $E / E^{\mathrm{obs}}$ is 0.84 . Therefore, the underestimations of evaporation and storage change are highly correlated.

The correlation between underestimations of evaporation and storage change may be due to the form of the equations for evaporation and storage change. To investigate this possibility, the following equation derivations are presented. Based on the definition of storage change, $\Delta S / \Delta \mathrm{TS}$ can be described as

$\frac{\Delta S}{\Delta \mathrm{TS}}=\frac{S_{t-1}-S_{t}}{Q_{t}+E_{t}^{\mathrm{obs}}}$.

Assuming late stage recession conditions apply and substituting Eq. (5b) into Eq. (13), one obtains

$\frac{\Delta S}{\Delta \mathrm{TS}}=\frac{1}{a_{2}\left(2-b_{2}\right)} \frac{Q_{t-1}^{2-b_{2}}-Q_{t}^{2-b_{2}}}{Q_{t}+E_{t}^{\mathrm{obs}}}$.

Since $Q_{t} \ll E_{t}^{\mathrm{obs}}$,

$$
\begin{aligned}
& \frac{\Delta S}{\Delta T S} \approx \frac{1}{a_{2}\left(2-b_{2}\right)} \frac{Q_{t-1}^{2-b_{2}}-Q_{t}^{2-b_{2}}}{E_{t}^{\mathrm{obs}}} \\
& =\frac{1}{a_{2}\left(2-b_{2}\right)} \frac{Q_{t-1}^{2-b_{2}}-Q_{t}^{2-b_{2}}}{E_{t}} \alpha .
\end{aligned}
$$

Substituting Eq. (4) into Eq. (15),

$\frac{\Delta S}{\Delta \mathrm{TS}} \approx \frac{1}{a_{2}\left(2-b_{2}\right)} \frac{Q_{t-1}^{2-b_{2}}-Q_{t}^{2-b_{2}}}{\frac{-\mathrm{d} Q_{t} / \mathrm{d} t}{a_{2}} Q_{t}^{1-b_{2}}-Q_{t}} \alpha$.

Based on Eq. (16), the correlation between $\Delta S / \Delta \mathrm{TS}$ and $E / E^{\text {obs }}$ is affected by the variability of the term $\frac{Q_{t-1}^{2-b_{2}}-Q_{t}^{2-b_{2}}}{\frac{-\mathrm{d} Q_{t} / \mathrm{d} t}{a_{2}} Q_{t}^{1-b_{2}}-Q_{t}}$.
The value of $\beta$ can also be interpreted as the percentage of water storage contributing to the base flow during low flow periods when riparian groundwater storage is the major source for base flow. Column 5 in Table 2 shows the relative storage computed with Eq. (5) and the last column shows the values of $\beta$ estimated by Eq. (12) from water balance. As shown in Table $2, \beta$ does not change significantly during a recession event. The value of $\beta$ is around 0.43 for the Spoon River watershed and varies from 0.38 to 0.32 for the Nodaway River watershed. Compared with the declining trend of $\alpha$ during a recession event, the value of $\beta$ is relatively more stable. The implication of a stable value of $\beta$ is that the ratio of riparian groundwater storage to total watershed groundwater storage is relatively stable during a recession event.

To mathematically investigate the cause of stable $\beta$ values during recession events, a general form of $\beta_{t}$ is obtained:

$\beta_{t}=\frac{S_{t}}{\frac{S_{0}}{\bar{\alpha}}-\sum_{i=1}^{t} Q_{i}-\sum_{i=1}^{t} \mathrm{TE}_{i}}$,

where $S_{0}$ is the initial storage, $S_{t}$ is storage at time $t$, and $\bar{\alpha}$ is the initial value of $\beta$. Since $\Delta \mathrm{TS}_{i}=-\left(\Delta Q_{i}+\Delta \mathrm{TE}_{i}\right)$, Eq. (17) can be written as:

$\beta_{t}=\frac{S_{0}+\sum_{i=1}^{t} \Delta S_{i}}{\frac{S_{0}}{\bar{\alpha}}+\sum_{i=1}^{t} \Delta \mathrm{TS}_{i}}$.

If $S_{0} \gg \sum_{i=1}^{t} \Delta S_{i}$ and $\frac{S_{0}}{\bar{\alpha}} \gg \sum_{i=1}^{t} \Delta \mathrm{TS}_{i}, \beta_{t}$ will be close to $\bar{\alpha}$, which is constant during the recession event. Figure 9a shows $\sum_{i=1}^{t} \Delta S_{i} \quad \sum_{i=1}^{t} \Delta \mathrm{TS}_{i}$ $\frac{i=1}{S_{0}}, \frac{\sum_{i=1}}{\Delta T S_{0}}$, and $\beta_{t}$ for the event shown in Table 2a for the Spoon River watershed. Values of $\frac{\sum_{i=1}^{t} \Delta S_{i}}{S_{0}}$ and $\frac{\sum_{i=1}^{t} \Delta T S_{i}}{\Delta \mathrm{TS}_{0}}$ are indeed small (around 0.1) and the values of $\beta_{t}$ are relatively stable (the range of variability is within 0.05 ). However, the initial storage varies seasonally and from event to event. Figure 9b shows three values for an event in October 1988 for the Spoon River watershed. In this event, values of $\frac{\sum_{i=1}^{t} \Delta S_{i}}{S_{0}}$ and $\frac{\sum_{i=1}^{t} \Delta \mathrm{TS}_{i}}{\Delta \mathrm{TS}_{0}}$ are as high as 0.4 and, similar to Figure $9 \mathrm{a}$, the range of variability of $\beta_{t}$ is within 0.05 . A similar pattern is observed in other watersheds as well. Of the 9 study watersheds, the Big Nemaha River watershed generally has the lowest water storage. Figure 10 shows two recession events in the Big Nemaha River watershed. The range of variability of $\beta_{t}$ is within 0.05 when the values of $\frac{\sum_{i=1}^{t} \Delta S_{i}}{S_{0}}$ and $\frac{\sum_{i=1}^{t} \Delta \mathrm{TS}_{i}}{\Delta \mathrm{TS}_{0}}$ are as low as 0.2 in Fig. 10a or as high as 0.4 in Fig. 10b. As shown in the results from the two watersheds, although 

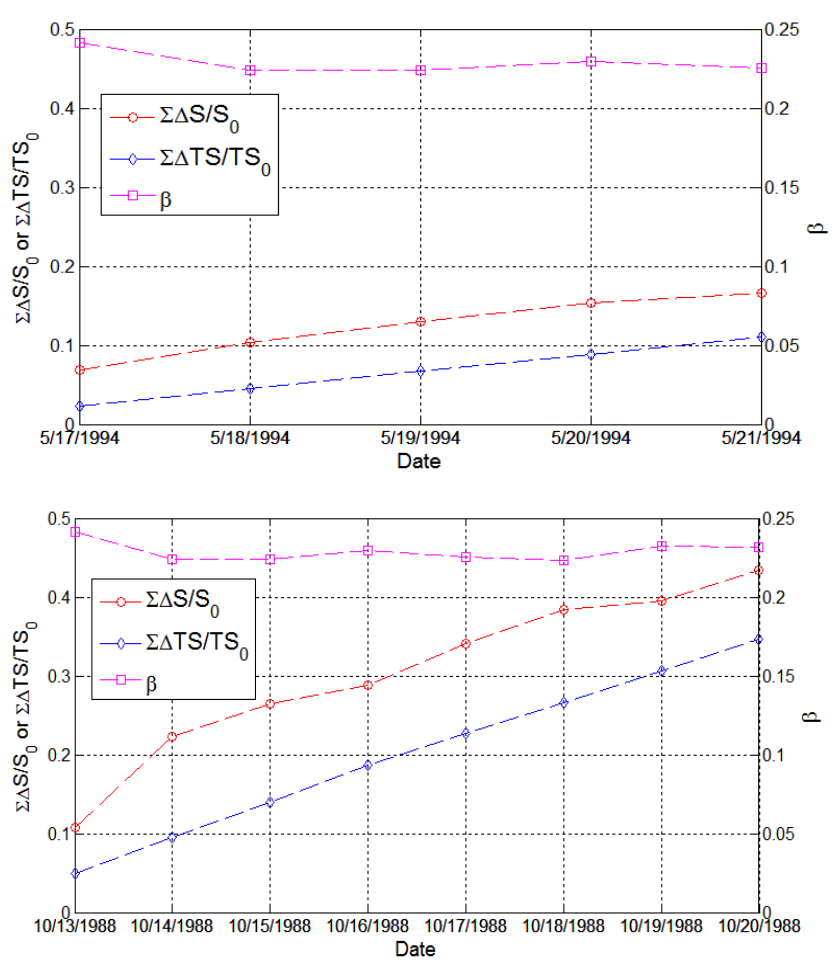

Fig. 9. Change of $\sum \Delta S / S_{0}, \sum \Delta \mathrm{TS} / \mathrm{TS}_{0}$ and $\beta$ during two recession events in the Spoon River watershed: (a) May 1994 and (b) October 1988 .

the large difference between $\Delta S$ and $S_{0}$ and the constant $\bar{\alpha}$ can contribute to the stability of the $\beta$ value, it is not the only factor.

On the other hand, $\beta$ reflects the level of shallow groundwater connectivity in the watershed. The groundwater storage connectivity is dependent on the groundwater table depth. Therefore, the value of $\beta$ may be correlated with groundwater table depth. It is fortunate that the observations of the shallow groundwater table depth in the Spoon River watershed are available (Wang, 2012a). As shown in Fig. 11, the values of $\beta$ decrease as the groundwater table depth increases. In this figure, the correlation coefficient is 0.41 , which indicates that when the groundwater table drops, the contributing storage to base flow will decrease. The seasonal variability of water table depth is significant, ranging from 86 to $510 \mathrm{~mm}$, as shown in Fig. 11. Correspondingly, the seasonal variability of $\beta$ is also significant, ranging from 0.027 to 0.799 (Fig. 11), even though the variation of $\beta$ is not significant during a recession event.

\subsection{Variability of storage-discharge relationship}

The underestimation of evaporation and storage, which are represented by $\alpha$ and $\beta$, is caused by the effect of partial contributing storage during recession events. To show the storage dynamics during recession events, and therefore to provide a
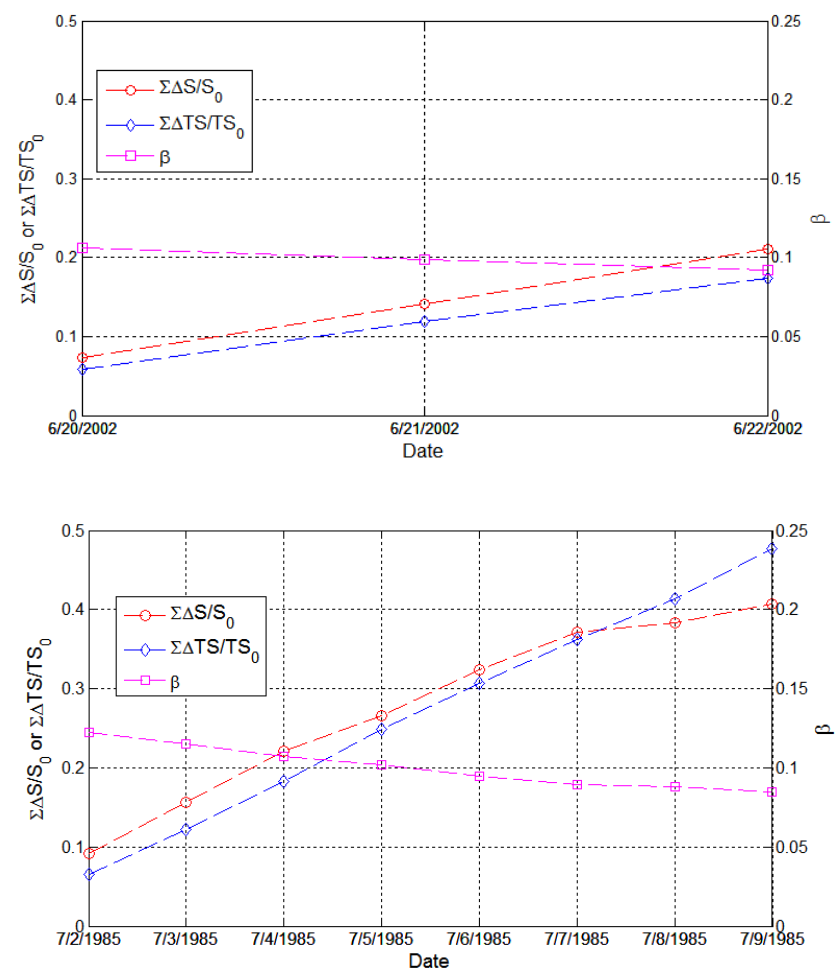

Fig. 10. Change of $\sum \Delta S / S_{0}, \sum \Delta \mathrm{TS} / \mathrm{TS}_{0}$ and $\beta$ during two recession events in the Big Nemaha River watershed: (a) June 2002 and (b) July 1985 .

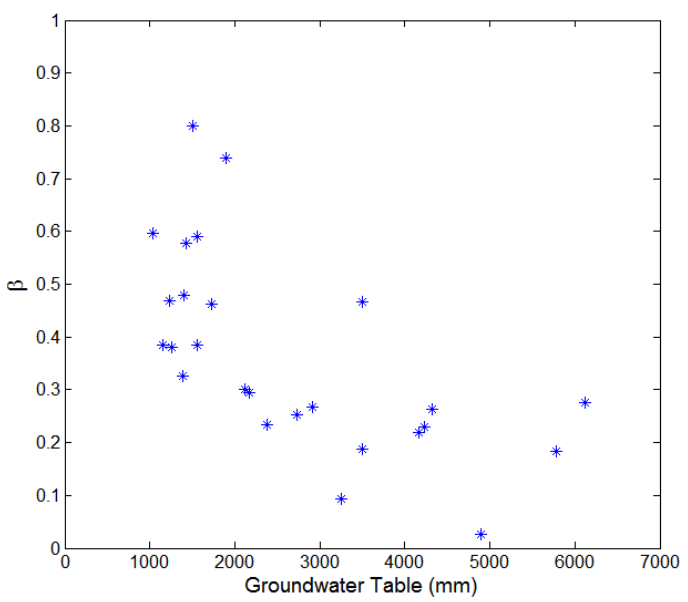

Fig. 11. The relationship between estimated $\beta$ and observed shallow groundwater table depth at the Spoon River watershed.

more detailed presentation of partial contributing storage, the idea of 4-stage storage seasonality is applied in the recession events in the Spoon River watershed (Heidbüchel et al., 2012; Hrachowitz et al., 2013). Based on the level of contributing storage $S$ and total storage TS calculated using Eqs. (5) and (9) respectively, the recession events are sorted into 4 stages: (1) dry, (2) wetting-up, (3) wet and (4) drying-down. Dry 


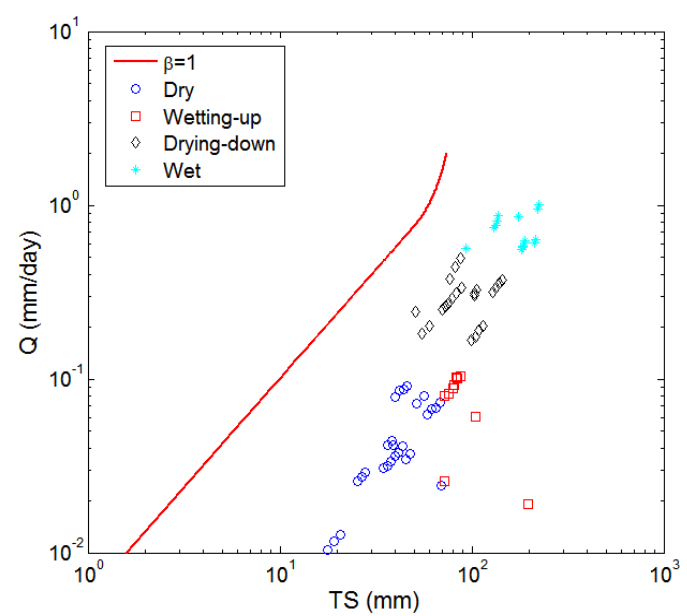

Fig. 12. The impact of variable contributing storage on the total storage-discharge relationship at the Spoon River watershed in 4 storage stages.

stage is defined as the period when both $S$ and TS are low, to be more specific, when $S<0.25 S_{\max }$ and TS $<0.25 \mathrm{TS}_{\max }$, in which $S_{\max }$ and $\mathrm{TS}_{\max }$ represent the maximum values of contributing storage and total storage during recession events, respectively. Similarly, wet stage is defined as the period when $S>0.75 S_{\max }$ and TS $>0.75 \mathrm{TS}_{\max }$. The transitional conditions are combined with the wetting-up stage or drying-down stage. The wetting-up stage is defined as the period when $S<0.25 S_{\max }$ and TS $>0.25 \mathrm{TS}_{\max }$. During this stage, the total storage is wetting-up but the contributing storage is still low. The drying-down stage is defined as the period when $S>0.25 S_{\max }$ and $\mathrm{TS}<0.75 \mathrm{TS}_{\max }$. The condition when $0.25 S_{\max }<S<$ $0.75 S_{\max }$ and $0.25 \mathrm{TS}_{\max }<\mathrm{TS}<0.75 \mathrm{TS}_{\max }$ is defined as in the drying-down stage, because most of the events in this condition are in the summer, when storage is generally declining in the Spoon River watershed.

Figure 12 presents the estimated total relative storage (TS) and discharge $(Q)$ relationship for the Spoon River watershed as the recession events are sorted into 4 storage stages as described previously. The red solid line represents the storage-discharge function derived from the lower envelope in Fig. 1, i.e., Eq. (5), which is equivalent to the case of $\beta=1$. The blue circles, red squares, black diamonds and cyan stars represent the estimated total watershed relative storage by considering variable $\beta$ values based on water balance at the watershed scale at the 4 storage stages, respectively. The data points $(\beta<1)$ are below the red solid line $(\beta=1)$. From Fig. 12 , the TS $-Q$ relationship tends to follow a power law within a recession event but varies among different recession events due to the variability of $\beta$ between individual recession events. Given the same values of total watershed water storage, the corresponding discharge may vary between recession events. Furthermore, the storagedischarge relationship between different storage stages varies significantly. With the same level of TS, recession events in the wetting-up stage have a much lower discharge than in the drying-down stage. In the wetting-up stage, storage in the unsaturated zone increases but the contributing storage in the saturated zone has not yet increased (Hrachowitz et al., 2013). Furthermore, the difference between storage stages is also shown in the relationship between $\alpha$ and $Q$ as shown in Fig. 5. With the same level of $\alpha$ value, the base flow is higher in the drying-down stage than in the wetting-up stage.

Therefore, the storage-discharge relationship during recession periods may not be a one-to-one function. The multi-storage theory, on which the 4-stage storage method is based on, matches well with the partial contributing hypothesis in this study, as shown above. Besides these two, other factors can also contribute to the multi-valued storage-discharge relationship (Rupp et al., 2009; Haught and Meerveld, 2011; Clark et al., 2011). Furthermore, human activities can also alter the base flow recession (Wang and Cai, 2009, 2010). Sloan (2000) demonstrated that singlevalued storage-discharge functions are often incapable of representing the actual storage-discharge characteristics of a watershed and proposed an alternative discharge function based on hillslope groundwater hydraulics.

\section{Summary and conclusion}

The impact of subsurface hydrologic connectivity, which is represented by the partial contributing storage, on the storage-discharge functions of 9 watersheds in different climate regions was evaluated. The hydrologic connection among hillslope-riparian-stream zones decreases with the decline of the water table. The effect of the partial contributing storage is one possible cause for the multi-valued storage-discharge relationship. The seasonal variations of hydrologic connectivity and contributing storage can cause variable storage-discharge functions given the same value of streamflow. As a result, when the entire watershed storage is assumed to be connected with the watershed outlet, water storage and evaporation based on the storage-discharge function may be underestimated systematically. The underestimation of evaporation and storage change based on the storage-discharge function was evaluated using $\alpha$ as the ratio between estimated evaporation and remote sensed evaporation and $\beta$ as the ratio between estimated storage and total storage, respectively. Based on the values of $\alpha$ and $\beta$, significant underestimation was observed for both evaporation and storage. The value of $\alpha$ decreases during a recession event. On the other hand, the value of $\beta$ is relatively stable during a recession event, while it varies significantly among different recession events.

It should be noted that other factors may also contribute to the multi-valued storage-discharge relationship (Rupp et al., 2009; Haught and Meerveld, 2011; Clark et al., 2011; Wang and Cai, 2009, 2010). Multiple-reservoir models can 
generate multi-valued storage-discharge relationships even in the absence of evapotranspiration (Moore, 1997). In this paper, the partial contributing storage effect is one possible cause for the multi-valued storage-discharge relationship. The storage dynamic is also analyzed in this study based on the 4-stage storage seasonality method.

The effect of partial contributing storage on storagedischarge functions increases with the spatial heterogeneity of water storage. In small catchments, it may be reasonable to assume a fixed storage-discharge function. However, information on the spatial variability of storage may need to be incorporated into the lumped storage-discharge function for watersheds with significant seasonality of water table dynamics. Further research will be focused on validating partial contributing storage in experimental watersheds with detailed observations on spatial variability of soil moisture and the groundwater table as well as the response of base flow to these factors.

\section{Supplementary material related to this article is available online at http://www.hydrol-earth-syst-sci.net/ 17/4283/2013/hess-17-4283-2013-supplement.pdf.}

Acknowledgement. This research was funded in part under Award No. NA10OAR4170079 from the Florida Sea Grant and Award No. NA10NOS4780146 from the National Oceanic and Atmospheric Administration (NOAA) Center for Sponsored Coastal Ocean Research (CSCOR). The authors are grateful for the constructive comments, which lead to improvement of this manuscript, by three reviewers and the associate editor.

Edited by: M. Hrachowitz

\section{References}

Ajami, H., Troch, P. A., Maddock III, T., Meixner, T., and Eastoe, C.: Quantifying mountain block recharge by means of catchment-scale storage-discharge relationships, Water Resour. Res., 47, W04504, doi:10.1029/2010WR009598, 2011.

Beven, K.: Searching for the Holy Grail of scientific hydrology: $Q_{t}=(S, R, \delta t) A$ as closure, Hydrol. Earth Syst. Sci., 10, 609618, doi:10.5194/hess-10-609-2006, 2006.

Biswal, B. and Marani, M.: Geomorphological origin of recession curves, Geophys. Res. Lett., 37, L24403, doi:10.1029/2010GL045415, 2010.

Blyth, K. and Rodda, J. C.: A stream length study, Water Resour. Res., 9, 1454-1461, 1973.

Brutsaert, W. and Nieber, J. L.: Regionalized drought flow hydrographs from a mature glaciated plateau, Water Resour. Res., 13, 637-644, doi:10.1029/WR013i003p00637, 1977.

Buttle, J. M., Dillon, P. J., and Eerkes, G. R.: Hydrologic coupling of slopes, riparian zones and streams: an example from the Canadian Shield, J. Hydrol., 287, 161-177, 2004.

Changnon, S. A., Huff, F. A., and Hsu, C.: Relations Between Precipitation and Shallow Groundwater in Illinois, J. Climate, 1, 1239-1250, 1988.
Clark, M. P., Rupp, D. E., Woods, R. A., Tromp-van Meerveld, H. J., Peters, N. E., and Freer, J. E.: Consistency between hydrological models and field observations: Linking processes at the hillslope scale to hydrological responses at the watershed scale, Hydrol. Process., 23, 311-319, doi:10.1002/hyp.7154, 2009.

Clark, M. P., McMillan, H. K., Collins, D. B. G., Kavetski, D., and Woods, R. A.: Hydrological field data from a modeller's perspective: Part 2: process-based evaluation of model hypotheses, Hydrol. Process., 25, 523-543, doi:10.1002/hyp.7902, 2011.

Daniel, J. F.: Estimating groundwater evaporation from streaflow records, Water Resour. Res., 12, 360-364, doi:10.1029/WR012i003p00360, 1976.

Day, J. C.: International Aquifer Management: The Hueco Bolson on the Rio Grande River, National Resource J., 18, 163-179, 1978.

Demissie, M., Keefer, L., Lian, Y., and Yue, F.: The importance of managing sedimentation in the Cache River wetlands, in: Restoring our natural habitat: proceedings of the 2007 World Environmental and Water Resources Congress: 15-19 May 2007, Tampa, Florida, Reston, VA, American Society of Civil Engineers, 10 pp., doi:10.1061/40927(243)626, 2007.

Ding, J. Y.: Discussion of "Inflow hydrographs from large unconfined aquifers" by H. A. Ibrahim and W. Brutsaert, J. Irrig. Drain. Div. Am. Soc. Civ. Eng., 92, 104-107, 1966.

Ding, J.: Interactive comment on: "Are streamflow recession characteristics really characteristic?; by M. Stoelzle et al. (2012), Hydrol. Earth Syst. Sci. Discuss., 9, C4378-C4381, 2012.

Duan, Q., Schaake, J., Andréassian, V., Franks, S., Goteti, G., Gupta, H. V., Gusev, Y. M., Habets, F., Hall, A., Hay, L., Hogue, T., Huang, M., Leavesley, G., Liang, X., Nasonova, O. N., Noilhan, J., Oudin, L., Sorooshian, S., Wagener, T., and Wood, E. F.: The Model Parameter Estimation Experiment (MOPEX): An overview of science strategy and major results from the second and third workshops, J. Hydrol., 320, 3-17, 2006.

Ewen, J. and Birkinshaw, S. J.: Lumped hysteretic model for subsurface stormflow developed using downward approach, Hydrol. Process., 21, 1496-1505, 2007.

Federer, C. A.: Forest transpiration greatly speeds streamflow recession, Water Resour. Res., 9, 1599-1604, 1973.

Gregory, P. W.: The Water Quality of Streamflow from Ponderosa Pine Forests on Sedimentary Soils, MSc thesis, The University of Arizona, 1976.

Harman, C. J., Sivapalan, M., and Kumar, P.: Power law catchment-scale recessions arising from heterogeneous linear small-scale dynamics, Water Resour. Res., 45, W09404, doi:10.1029/2008WR007392, 2009.

Haught, D. R. W. and van Meerveld, H. J.: Spatial variation in transient water table responses: differences between an upper and lower hillslope zone, Hydrol. Process., 25, 3866-3877, doi:10.1002/hyp.8354, 2011.

Heidbüchel, I., Troch, P. A., Lyon, S. W., and Weiler, M.: The master transit time distribution of variable flow systems, Water Resour. Res., 48, W06520, doi:10.1029/2011WR011293, 2012.

Hollinger, S. E. and Isard, S. A.: A soil moisture climatology of Illinois, J. Climate, 7, 822-833, 1994.

Hrachowitz, M., Savenije, H., Bogaard, T. A., Tetzlaff, D., and Soulsby, C.: What can flux tracking teach us about water age distribution patterns and their temporal dynamics?, Hydrol. Earth Syst. Sci., 17, 533-564, doi:10.5194/hess-17-533-2013, 2013. 
Illinois Department of Natural Resources: Spoon River Area Assessment: Volume 1: Geology, IDNR, Springfield, IL, 1998.

Illinois State Water Surer: Illinois Monthly Evaporation Data, available at: http://www.isws.illinois.edu/atmos/statecli/Pan-Evap/ panevapx.htm (last access: 17 April 2013), 2010.

Jencso, K. G., McGlynn, B. L., Gooseff, M. N., Wondzell, S. M., Bencala, K. E., and Marshall, L. A.: Hydrologic connectivity between landscapes and streams: Transferring reach- and plot-scale understanding to the catchment scale, Water Resour. Res., 45, W04428, doi:10.1029/2008WR007225, 2009.

Kirchner, J. W.: Watersheds as simple dynamical systems: watershed characterization, rainfall-runoff modeling, and doing hydrology backward, Water Resour. Res., 45, W02429, doi:10.1029/2008WR006912, 2009.

Krakauer, N. Y. and Temimi, M.: Stream recession curves and storage variability in small watersheds, Hydrol. Earth Syst. Sci., 15, 2377-2389, doi:10.5194/hess-15-2377-2011, 2011.

McDonnell, J. J., Brammer, D., Kendall, C., Hjerdt, N., Rowe, L., Stewart, M., and Woods, R.: Flow pathways on steep forested hillslopes: the tracer, tensiometer and trough approach, in: Environmental Forest Science, edited by: Tani, M., Kluwer, Dordrecht, 463-474, 1998.

Molenat, J., Gascuel-Odoux, C., Ruiz, L., and Gruau, G.: Role of water table dynamics on stream nitrate export and concentration in agricultural headwater catchment, J. Hydrol., 348, 364-378, 2008.

Moore, R. D.: Storage-outflow modelling of streamflow recessions, with application to a shallow-soil forested catchment, J. Hydrol., 198, 260-270, 1997.

Mu, Q., Ann Heinsch, F., Zhao, M., and Running, S. W.: Development of a global evaporation algorithm based on MODIS and global meteorology data, Remote Sens. Environ., 111, 519-536, 2007.

Ocampo, C. J., Sivapalan, M., and Oldham, C. E.: Hydrological connectivity of upland-riparian zones in agricultural catchments: Implications for runoff generation and nitrate transport, J. Hydrol., 331, 643-658, 2006.

Palmroth, S., Katul, G. G., Hui, D., McCarthy, H. R., Jackson, R. B., and Oren, R.: Estimation of long-term basin scale evaporation from streamflow time series, Water Resour. Res., 46, W10512, doi:10.1029/2009WR008838, 2010.

Rodhe, A. and Seibert, J.: Groundwater dynamics in a till hillslope: flow directions, gradients and delay, Hydrol. Process., 25, 18991909, doi:10.1002/hyp.7946, 2011.

Rupp, D. E., Schmidt, J., Woods, R. A., and Bidwell, V. J.: Analytical assessment and parameter estimation of a low-dimensional groundwater model, J. Hydrol., 377, 143-154, 2009.

Sayama, T., McDonnell, J., Dhakal, A., and Sullivan, K.: How much water can a watershed store?, Hydrol. Process. 25, 3899-3908, doi10.1002/hyp.8288, 2011.

Scott, R. W., Krug, E. C., and Burch, S. L.: Illinois Soil Moisture under Sod Experiment, J. Hydrometeor., 11, 683-704, doi:10.1175/2009JHM1130.1, 2010.

Seibert, J., Bishop, K., Rodhe, A., and McDonnell, J. J.: Groundwater dynamics along a hillslope: A test of the steady state hypothesis, Water Resour. Res., 39, 1014, doi:10.1029/2002WR001404, 2003.
Sloan, W. T.: A physics-based function for modeling transient groundwater discharge at the watershed scale, Water Resour. Res., 36, 225-241, 2000

Spence, C., Guan, X. J., Phillips, R., Hedstorm, N., Granger, G., and Reid, B.: Storage dynamics and streamflow in a catchment with a variable contributing area, Hydrol. Process., 24, 2209-2221, doi:10.1002/hyp.7492, 2010.

Stoelzle, M., Stahl, K., and Weiler, M.: Are streamflow recession characteristics really characteristic?, Hydrol. Earth Syst. Sci., 17 817-828, doi:10.5194/hess-17-817-2013, 2013.

Swenson, S., Yeh, P. J.-F., Wahr, J., and Famiglietti, J.: A comparison of terrestrial water storage variations from GRACE with in situ measurements from Illinois, Geophys. Res. Lett., 33, L16401, doi:10.1029/2006GL026962, 2006.

Szilagyi, J., Gribovszki, Z., and Kalicz, P.: Estimation of catchmentscale evaporation from baseflow recession data: Numerical model and practical application results, J. Hydrol., 336, 206217.2007

Teuling, A. J., Lehner, I., Kirchner, J. W., and Seneviratne, S. I.: Catchments as simple dynamical systems: Experience from a Swiss prealpine catchment, Water Resour. Res., 46, W10502, doi:10.1029/2009WR008777, 2010.

Tromp-van Meerveld, H. J. and McDonnell, J. J.: Threshold relations in subsurface stormflow: 1. A 147-storm analysis of the Panola hillslope, Water Resour. Res., 42, W02410, doi:10.1029/2004WR003778, 2006a.

Tromp-van Meerveld, H. J. and McDonnell, J. J.: Threshold relations in subsurface stormflow: 2 . The fill and spill hypothesis, Water Resour. Res., 42, W02411, doi:10.1029/2004WR003800, 2006b.

Vidon, P.: Towards a better understanding of riparian zone water table response to precipitation: surface water infiltration, hillslope contribution or pressure wave processes?, Hydrol. Process., 26, 3207-3215, doi:10.1002/hyp.8258, 2012.

Vidon, P. and Hill, A. R.: Landscape controls on nitrate removal in stream riparian zones, Water Resour. Res., 40, W03201, doi:10.1029/2003WR002473, 2004.

Vogel, R. and Kroll, C.: Regional geohydrologic-geomorphic relationships for the estimation of low-flow statistics, Water Resour. Res., 28, 2451-2458, 1992.

Wagener, T., Sivapalan, M., Troch, P., and Woods, R.: Catchment classification and hydrologic similarity, Geography Compass, 1/4, 901-931, doi:10.1111/j.1749-8198.2007.00039.x, 2007.

Wang, D.: On the base flow recession at the Panola Mountain Research Watershed, Georgia, USA, Water Resour. Res., 47, W03527, doi:10.1029/2010WR009910, 2011.

Wang, D.: Evaluating interannual water storage changes at watersheds in Illinois based on long-term soil moisture and groundwater level data, Water Resour. Res., 48, W03502, doi:10.1029/2011WR010759, 2012a.

Wang, D.: Assessing the impact of subsurface storage contributing area on the watershed scale storage-discharge function derived from baseflow recession at the Spoon River in Illinois, ASCE-World Environmental and Water Resources Congress in Albuquerque, New Mexico, 20-24 May, 3770-3779, doi:10.1061/9780784412312.379, 2012b.

Wang, D. and Cai, X.: Detecting human Interferences to low flows through base flow recession analysis, Water Resour. Res., 45, W07426, doi:10.1029/2009WR007819, 2009. 
Wang, D. and Cai, X.: Comparative study of climate and human impacts on seasonal base flow in urban and agricultural watersheds, Geophys. Res. Lett., 37, L06406, doi:10.1029/2009GL041879, 2010.

Wittenberg, H. and Sivapalan, M.: Watershed groundwater balance estimation using streamflow recession analysis and base flow separation, J. Hydrol., 219, 20-33, 1999.
Yeh, P., Irizarry, M., and Eltahir, E.: Hydroclimatology of Illinois: A comparison of monthly evaporation estimates based on atmospheric water balance and soil water balance, J. Geophys. Res., 103, 19823-19837, 1998.

Zhang, K., Kimball, J. S., Nemani, R. R., and Running, S. W. A continuous satellite-derived global record of land surface evaporation from 1983-2006, Water Resour. Res., 46, W09522, doi:10.1029/2009WR008800, 2010. 